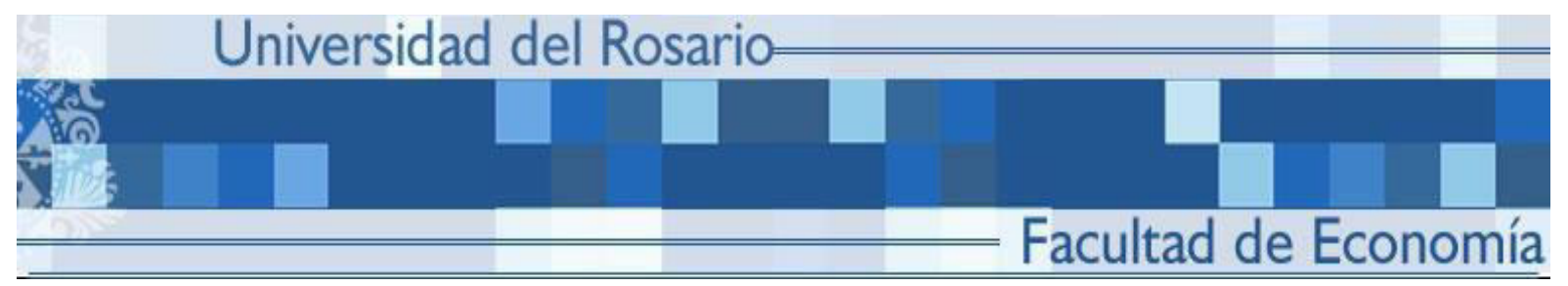

The Value of Political Capital: Dictatorship Collaborators as Business Elites

Felipe González

Mounu Prem

SERIE DOCUMENTOS DE TRABAJO

No. 213

Enero de 2018 


\title{
The Value of Political Capital: \\ Dictatorship Collaborators as Business Elites*
}

\author{
Felipe González ${ }^{\dagger} \quad$ Mounu Prem ${ }^{\ddagger}$
}

\begin{abstract}
What is the value of political capital for individuals? Towards the end of the Pinochet dictatorship in Chile, military and civilian collaborators entered the business elite, controlling the largest and most important firms in the country. Using a novel panel dataset of board members in these firms, we document a work premium for those who had previously collaborated with Pinochet. After democratization, however, collaborators were removed from boards and their compensation premium disappeared, suggesting that the value of their networks depreciated. To shed light on these findings, we study military personnel before, during, and after Pinochet and find evidence of a wage premium only during the dictatorship. We interpret these results as Pinochet favoring his collaborators while he was in power.
\end{abstract}

Keywords: political capital, collaborators, dictatorship, armed forces

\footnotetext{
*January, 2018. We would like to thank Nicolás Grau, José Ignacio Heresi, Borja Larraín, Pepita Miquel-Florensa, Pablo Muñoz, Pablo Querubín, Edoardo Teso, Samuel Tschorne, Francisco Urzúa, Nico Vöigtlander, David Yang and seminar participants at UC Berkeley and Universidad del Rosario for comments and suggestions. We also thank Andrés Felipe Rivera and Cristine von Dessauer for outstanding research assistance as well as the Economic History Association, the Center for Effective Global Action, Fondecyt (Project 11170258), and the Stanford Center for International Development for financial support.

†Pontificia Universidad Católica de Chile, Instituto de Economía. E-mail: fagonza4@uc.cl.

$\ddagger$ Universidad del Rosario, Department of Economics.
} 


\section{Introduction}

Firms hire board members for their managerial skills and monitoring capacity (Adams et al., 2010; Schwartz-Ziv and Weisbach, 2013), but also for their social networks. A large body of research has shown that firms benefit from one type of network, political connections or political capital. ${ }^{1}$ If these connections are valuable, then we should observe that individuals with valuable networks earn a premium for them. Moreover, this premium should generally disappear if valuable links cease to exist or if the value of the connections depreciates. Although intuitive, it has proven difficult to empirically identify this premium.

In this paper we show the existence of a work premium among individuals with links to the Pinochet regime before Chile's transition to democracy. Towards the end of the Pinochet dictatorship (1973-1990), a number of his collaborators entered the business elite as board members of the largest and most important firms in the country. These individuals had previously worked for the regime as part of the military or as civilians in cabinet positions. We collect data on the universe of board members in listed and non-listed firms, and information on their board compensation for almost a decade, covering periods of both dictatorship and democracy. We exploit variation within individual-firm pairs and show Pinochet collaborators were on more boards, had higher compensation, and were placed in higher positions than other board members. Importantly, this "work premium" among collaborators disappeared after democratization.

Several aspects of the Pinochet regime make it a useful and interesting case study. In the first place, the timing of this democratization allows us to observe the situation of collaborators and other board members in both the dictatorship and democracy. Chile's transition to democracy started in October 1988, when Pinochet lost a referen-

\footnotetext{
${ }^{1}$ See Fisman (2001), Khwaja and Mian (2005), Faccio (2006), Faccio et al. (2006), Jayachandran (2006), Claessens et al. (2008), Ferguson and Voth (2008), Blanes i Vidal et al. (2012), Cingano and Pinotti (2013), Acemoglu et al. (2016), Fisman and Wang (2015), González and Prem (2017), and Colonnelli and Prem (2017), among many others.
} 
dum, and concluded in March 1990 when Patricio Aylwin became the first democratically elected President since 1970. The transition to democracy was unexpected and changed the political nature of the following eight years. As a consequence of this common type of democratization (Treisman, 2017), collaborators lost their political networks and their social capital depreciated.

In the second place, data availability allows us to measure several important dimensions that are usually unavailable to researchers. We combine an administrative data set of board members in the largest firms in the country - which includes listed and non-listed firms - with a procedure that uses internet content to identify dictatorship collaborators. In addition, we are able to observe board compensation for the majority of individuals on these boards.

We find that collaborators enjoyed a significant work premium during the dictatorship. In particular, we observe that within firms, collaborators were placed in more and higher positions, and had 10\% higher board compensation. In addition, we use the panel structure in our data in a differences-in-differences framework to exploit within board member variation and estimate how this work premium changed after democratization. Results show that collaborators were removed from board positions, and those who remained suffered from a significant decrease in their board compensation. We identify this effect using a comparison between collaborators and other board members before and after Chile's transition to democracy. These changes in the work premium of dictatorship collaborators are similar for both military and civilian collaborators.

The disappearance of the work premium and the similarity of results across military and civilian collaborators suggest that the work premium cannot be explained by differences in managerial skills. Civilians had arguably different managerial skills than the military but had the same premium. To explain this work premium we use historical data to study active military personnel, a group that also collaborated but did not work at any firm. We document that military personnel earned twice the wage of public employees only during dictatorship. This wage premium did not ex- 
ist prior to the Pinochet regime, it originated in the mid-1970s as a consequence of legal reforms, and disappeared after democratization. Therefore, we argue that this wage premium is consistent with a favoritism mechanism. The size of the premium, its timing, and the historical context do not support other explanations. Although we cannot definitely prove that favoritism with military personnel implies favoritism with board members, the collection of findings points in that direction.

Overall, these findings suggest that individuals enjoy a premium if they have political and the premium is most likely to be explained by favors flowing from networks to individuals and finally to firms. Importantly, this premium is not guaranteed to exist forever, and we find evidence that it disappears when the value of networks decreases and political capital depreciates. The premium can be theoretically explained by either productivity or favoritism, and we provide suggestive evidence for the latter being relatively more important in our context.

The main contribution of this paper is to empirically document how the value that firms place on political capital translates into a premium for individuals providing said connections - specifically dictatorship collaborators - and to estimate how this premium changes after political capital depreciates. To the best of our knowledge, this type of analysis is novel. ${ }^{2}$ Indeed, we are shifting the focus in the political connections literature from firm value and performance (e.g., Fisman 2001, Ferguson and Voth 2008, Fisman et al. 2012, Amore and Bennedsen 2013, Kostovetsky 2015, among others), and firm-related outcomes (e.g., Khwaja and Mian 2005, Cingano and Pinotti 2013, among others) to the outcomes of individuals providing connections between the state and the business world. An exception is the work by Cohen et al. (2008), who show how connections between boards and mutual fund managers translate into higher performance for the latter. Nevertheless, we know relatively little about the premium obtained by individuals providing the connections.

\footnotetext{
${ }^{2}$ There is a significant amount of qualitative work about collaborators. For example, Salazar (1995) documents the history of the head of Pinochet's secret police, Woloch (2002) studies the contribution of collaborators to the rise of Napoleon in France, and Kaplan (2001) studies the fate of writer and Nazi supporter Robert Brasillach.
} 
Although we are not aware of any study analyzing how firms value dictatorship collaborators, there are a few papers that study individual-level outcomes in the private world as a function of networks in the public sphere. For example, Hsieh et al. (2011) find that citizens in Venezuela experienced higher unemployment rates and lower wages after being identified as opponents to the Chávez regime. Fisman et al. (2014) show that the assets of winners in state elections in India increase by 3-5\% when compared to assets of runners-up. Finally, Gagliarducci and Manacorda (2014) find that employment and wages are higher for Italians with a family member who is holding office.

The next section provides details about the Pinochet regime and dictatorship collaborators. Section 3 describes the data construction process and provides descriptive statistics. Section 4 presents main results, Section 5 discusses mechanisms by studying military personnel, and Section 6 concludes.

\section{Collaborators of the Pinochet Regime}

The dictatorship in Chile began in September 11th of 1973, when President Salvador Allende was overthrown in a coup d'état. Coup plotters included the Navy, the Air Force, the National Police, and the Army, the latter led by Commander-in-Chief Augusto Pinochet. In the aftermath of the operation, all political activities were suppressed, the Congress was closed, the Constitution was suspended, and a junta was established to rule the country. The leaders of the armed forces and the National Police were appointed as members of the junta, and Pinochet was designated head of the institution. In the following months, Pinochet consolidated his power and became (self-proclaimed) President of Chile in December of $1974 .{ }^{3}$

After taking political control of the country, the junta needed to fill positions in

\footnotetext{
${ }^{3}$ The other members of the junta were Gustavo Leigh (Air Force), José Toribio Merino (Navy), and César Mendoza (National Police). Pinochet left the junta in 1981 and José Toribio Merino replaced him as the head. Before 1981 the junta represented both the executive and legislative power, but after 1981 it acted only as a legislative body. This was the first time a junta was established since 1932.
} 
the government. There was, however, no clear strategy to recruit individuals willing to collaborate with the new regime. As stated by Cavallo et al. (2011, p. 25), "there were no plans, no names, just the agreement of assigning government departments to the armed forces and, hopefully, some civilians." The ministers of the first cabinet were designated by the junta in the following three weeks following the coup. The objective was to have a "functioning government as quickly as possible" (Spooner, 1999, p. 85). All designated ministers were part of the armed forces except for two who were civilians. In the months after the coup, there was significant turnover in government departments and little consensus on how to run the country.

Although the military coup was condemned both nationally and internationally, the junta still enjoyed considerable support among citizens. ${ }^{4}$ In the political arena, the prevailing parties' opinions were divided in a predictable manner. On one hand, the left-wing was against the authoritarian regime that overthrew the first socialist president. On the other hand, the right wing supported the coup; and the Christian Democrats, the largest political party, were divided in their support. Overall, many politicians from the center-right political spectrum were willing to collaborate with the regime. In fact, the right-wing coalition, comprised by the National Party and the Radical Party, saw in these turbulent times an opportunity to implement their policy platform without having to negotiate with the opposition. ${ }^{5}$

The arrival of civilian collaborators to the regime occurred quickly. Collaborators in the early stage of the regime came from two distinct groups that worked in relatively different areas. ${ }^{6}$ The first group was composed by highly educated individuals trained at the University of Chicago, known as "Chicago Boys." These technocrats

\footnotetext{
4"During the regime's first few days in power, the defense ministry received an avalanche of letters, telegrams, flowers, and other congratulations from Chileans backing the coup. There were donations of jewelry delivered to the central bank to help 'rebuild' the country." (Spooner, 1999, p. 87-88).

5 The rationale behind the implementation of radical economic policies in turbulent times should not surprise economists (see Rodrik 1996). The case of Chile has been extensively documented and discussed by Klein (2008).

${ }^{6}$ The interactions between these groups have been documented by Huneeus (2000), who argues that these groups shared a "long-term power strategy." Miguel Kast, Pinochet's Minister of Planning (1978-80), Labor (1980-82), and President of the Central Bank (1982), acted as bridge between groups.
} 
were in charge of the design and implementation of economic policies. That policy design is described in a lengthy document known as "The Brick," first created before the 1970 presidential election as an economic program for the right-wing candidate Jorge Alessandri.7 The implementation of these policies started in 1975 and were substantially moderated after the 1982 economic crisis. A prominent figure of this group was Sergio De Castro, Pinochet's Economy Minister between 1975 and 1982, member of several boards of directors after 1982, and the epitome of collaborators in our data.

The second group of collaborators was composed by politically oriented individuals who participated in the "Gremialism," a political group originating at the Catholic University in the late 1960s. The Gremialists were responsible for the design and implementation of the legal framework that is largely at work in contemporary Chile. The most well-known collaborator in this group was Jaime Guzmán, the intellectual writer of the 1980's constitution and the founder of the Independent Democratic Union in 1983. Guzmán's party supported Pinochet's regime, and remains a powerful political force today.

Both groups of collaborators worked together to design and implement reforms during the regime. One of the most controversial policies was the transfer of ownership of large firms from the public to the private sector. As a consequence of these privatizations, several civilian and military collaborators of the regime acquired control of the largest firms in the country. The controversy lies in how privatizations were implemented and who benefited from the process. Some firms were sold at prices lower than the market price, effectively transferring wealth from the state to politically connected individuals. ${ }^{8}$ A notable example comes from Pinochet's son-inlaw, Julio Ponce Lerou, who was appointed executive director of the world's largest producer of potassium nitrate, iodine, and lithium due to a privatization. Nowadays, Ponce Lerou is one of the richest people in the world with a wealth of 3.3 billion U.S.

\footnotetext{
7See Centro de Estudios Públicos (1992) for more details about the text. The first part is dedicated to a diagnosis of the country and the second part to economic policies.

${ }^{8}$ For example, the Steel Company of the Pacific was sold for 40 million U.S. dollars. It has been estimated that the firm's value was approximately 200 million U.S. dollars. Hernan Büchi, Pinochet's Minister of Finance (1985-1989) was in charge of running the company (Mönckeberg, 2015, p. 72-75).
} 
dollars (Carlyle 2013, Salazar 2015). This is not an exceptional case and by the late 1980s many dictatorship collaborators participated in the boards of the largest and most important firms in the country.

After fifteen years in power, and with many collaborators running the largest firms, Augusto Pinochet decided to validate his regime internationally. The referendum of October 1988, known as the "1988 Plebiscite," in which Pinochet ran as the only candidate, was intended to validate him as democratic leader. Although people were skeptical of the referendum, Pinochet lost and acknowledged his defeat. 9 Instead of continuing the regime for the following eight years (1988-1996), Pinochet's successor was decided in December 1989 in a presidential election with candidates from all parties. As expected, the opposition won the 1989 election, and Patricio Aylwin became the democratically elected president. Several pieces of evidence, including a large drop in Chile's stock market, suggest that this democratization was largely unanticipated by citizens and the dictatorship itself (González and Prem, 2017). According to Treisman (2017), a dictator overestimating his chances of winning an election is a relatively common type of democratization.

\section{Data}

\subsection{Dictatorship collaborators and the business elite}

We collect data on the universe of individuals working on the boards of listed and non-listed firms between 1986 and 1994. These firms are the largest in the country and their assets are equivalent to 70\% of Chile's GDP in 1990. Since 1985, all listed firms and non-listed firms with more than 500 shareholders have been mandated to report their financial activities to a regulatory agency at the end of each year. ${ }^{10}$ Board members in these firms are key as they decide the company's economic strategy and

\footnotetext{
9See Boas (2015) and González and Prem (2018) for more details about this election.

${ }^{10}$ The regulatory agency in charge of compiling the annual reports is called Superintendencia de Valores y Seguros. The equivalent of this agency in the U.S. is the Securities and Exchange Commission.
} 
monitor the actions of CEOs. ${ }^{11}$ We retrieve the full name of board members (and their unique national identifier) from these reports. There were 1,194 individuals working on the boards of 210 firms in 1987.

We classified board members as collaborators or non-collaborators by performing a Google search of their names and studying their employment history before 1988. ${ }^{12}$ This classification is feasible due to the vast amount of information available about individuals who participated in the dictatorship. In addition, heads of government departments and army officers are well-known, facilitating the search. Using this information, we classified an individual as a collaborator if he worked for the dictatorship before 1988 .

After studying the employment history of these 1,194 board members working in 1987 , we found $94(8 \%)$ to be collaborators. Although it is hard to evaluate the magnitude of this number, collaborators worked in relatively large firms (González and Prem, 2017) and had worked in different areas of the Pinochet regime: 27 were high-ranked officers of the armed forces, 15 were close (economic or legal) advisors, 27 worked as head of government departments, and 25 were politicians designated directly by Pinochet (e.g. local politicians). To study heterogenous effects we classify collaborators as military or civilian who, as emphasized by Benmelech and Frydman (2015), would have arguably different managerial skills.

From the previously discussed annual reports we collect several pieces of information for board members: their board compensation (in Chilean pesos), profession (e.g., economist), and their alma mater. Because profession and alma mater are sometimes not reported, we complement this data set using Google. Unfortunately, we cannot follow the same strategy to complement missing compensation data. In addition, since individuals get their national identifiers close to when they are born, and

\footnotetext{
${ }^{11}$ Board members are hired by minority shareholders and the firm's owner. The compensation of board members is set by the controlling shareholder. See Lefort and Urzúa (2008) for more details.

${ }^{12}$ We performed all searches in incognito mode to avoid personalized searches and facilitate replication. More precisely, we look in the first page of results using two different queries: (1) the full name of the board member, and (2) full name + Pinochet.
} 
we collected these numbers from annual statements, we can use them to estimate an individual's age.

We use two additional data sources in our empirical analysis. The first data source is Chile's nationally representative survey, conducted by the Ministry of Social Development once every 2-3 years since 1985. This survey contains information about the education and occupation of approximately 200,000 individuals. We use these data to estimate the wage distribution in 1987. The second data source we use is the Occupation Survey, conducted by the University of Chile since 1957. This survey contains information about the labor activities of approximately 5,000 randomly chosen households in Santiago, the capital of Chile. We use this second data source to estimate the wage premium of the military personnel before, during, and after the Pinochet regime using bureaucrats as comparison group.

\subsection{Descriptive statistics}

Figure 1 presents the compensation distribution of board members together with the wage distribution in Chile. The average employed individual in 1987 earned approximately \$4,000 annually (in 2015 USD) while the average board member in the same year had a compensation of $\$ 32,500$. The wage of an average board member lies at the 88 th percentile of the wage distribution of the general population, and approximately 10\% of board members were above the 99th percentile. Thus board members were part of the wealthiest individuals in the economy, a segment that is usually not observed in traditional representative surveys.

Table 1 describes the positions of board members during the dictatorship. The upper panel shows the number and type of positions. The average individual worked on 1.1 boards per year, a total of 3.2 boards during the three years of dictatorship observed, and worked for an average of 2.4 years for a firm. There are three types of positions in these boards: president, vice-president, and other. We say a board member had a "high position" if he was president or vice-president. This distinction is relevant because presidents and vice-presidents have higher compensation and more 
decision-making power. A quarter of board members worked in high positions.

To get a clearer picture of who these board members were, we present additional information in the middle and bottom panels of Table 1. Board members earned approximately $\$ 34,000$ annually (in 2015 USD), and had degrees in business, engineering, and law from the two most prestigious universities in the country: Catholic University and the University of Chile. Approximately $75 \%$ of collaborators were civilians and $25 \%$ were military. In sum, board members were highly educated individuals and part of the wealthiest group in society.

Finally, it is important to emphasize that collaborators were not randomly placed across firms. In Table 2 we show that the $35 \%$ of firms who had collaborators in their boards had on average more board members (7.6 versus 6.5), were larger in terms of assets, and had lower return over assets (0.12 versus 0.24). Interestingly, firms with and without collaborators were similar in terms of leverage, exports, and years since their foundation. Additionally, there is little differential reporting of compensation across firms with and without collaborators and, if anything, firms with collaborators report more compensation data. The empirical analysis that follows accounts for observable and unobservable differences across firms using firm-level fixed effects.

\section{Main Results}

We present results in four parts. Parts one, two, and three document the work premium of collaborators as business elite during the dictatorship, and the changes after democratization. The fourth part explores the mechanism by studying the wages of military personnel before, during, and after the Pinochet regime.

\subsection{The work premium of collaborators}

To test for the existence of a work premium among collaborators before the transition to democracy, we restrict attention to the years of dictatorship in our data - i.e. 1986 
and 1987 - and estimate the following regression equation:

$$
W_{i j t}=\rho \cdot \text { Collaborator }_{i}+\gamma x_{i}+\lambda_{t}+\eta_{j}+v_{i j t}
$$

where $W_{i j t}$ is the number of board positions per year, the number of high-positions per year, or board compensation measured in U.S. dollars of board member $i$ working in firm $j$ in year $t$. The coefficient of interest $\rho$ is associated to the variable Collaborator ${ }_{i}$, an indicator for board members who had collaborated with the Pinochet regime before 1988, and we interpret it as the average work premium of a collaborator. The vector $x_{i}$ contains indicators for university degree. Importantly, $\lambda_{t}$ is a year indicator, and $\eta_{j}$ is a firm-level fixed effect. Given the observed differences among firms where collaborators worked, controlling for firm-level unobserved differences is crucial. Finally, we estimate standard errors by clustering at the individual level.

Note that, when we estimate equation (I) using board compensation as dependent variable, we collapse observations in 1986 and 1987 to a single cross-section to increase efficiency due to missing observations. In addition to the previously discussed specification, we also present results of a potential heterogeneous work premium by splitting collaborators by their type of collaboration, i.e. militaries and civilians.

Table 3 presents results. Columns 1-4 show that dictatorship collaborators worked in 0.18 more boards per year and 0.24 more high-positions per year, differences that correspond to increases of 16 and 114 percent respectively when compared to the average board member. These differences are relatively higher among civilians and more imprecisely estimated in the case of military collaborators. Columns 5-8 show that collaborators earned on average between $\$ 4,000$ and $\$ 5,600$ more in compensation than other board members in the same firm, which implies a compensation premium between 13 and 18 percent. The compensation premium appears similar across military and civilian collaborators although the imprecision in our estimates does not allows us to reach a solid conclusion in this dimension.

All in all, we conclude that the data suggests the existence of a work premium for board members who had collaborated with the Pinochet regime. This work premium 
translates into participation in more boards, in higher positions, and with a higher compensation. In what follows, we estimate how this work premium changed after democratization.

\subsection{Participation in boards after democratization}

Did collaborators remain working as board members after democratization? We now estimate how the work of collaborators in boards changed after 1988. In particular, we estimate the following regression equation:

$$
Y_{i j k t}=\beta_{1} \cdot\left(C_{i} \times \text { Transition }_{t}\right)+\beta_{2} \cdot\left(C_{i} \times \text { Democracy }_{t}\right)+\lambda_{i j}+\zeta_{k t}+\varepsilon_{i j k t}
$$

where $Y_{i j k t}$ is an outcome of individual $i$, who worked in firm $j$, which operated in industry $k$, measured in year $t$. The indicator $C_{i}$ takes the value of one for dictatorship collaborators, Transition $t_{t}$ is an indicator variable for years 1989 and 1990, and Democracy ${ }_{t}$ is an indicator variable for years 1991-1994. Additionally, $\lambda_{i j}$ and $\zeta_{k t}$ are individual-firm and industry-year fixed effects which capture unobserved heterogeneity across board positions (individual-firm pairs) and industry unobserved shocks every year in our data. Finally, $\varepsilon_{i j k t}$ is an error term clustered by both individual and firm levels, capturing correlation of outcomes within individuals over time and within a board in a firm. We are interested in the parameters $\beta_{1}$ and $\beta_{2}$, which capture differences among dictatorship collaborators after Chile's democratization.

We use four employment outcomes to measure participation in the business elite and two different variables to identify collaborators. The first outcome is an indicator that takes the value of one if an individual was working in at least one board, and the second is the number of boards in which he worked at. The third outcome is an indicator that takes the value of one if an individual was working in at least one highposition (i.e. president or vice-president of a board), and the fourth outcome is the number of high-positions he works at. Regarding our identification of collaborators, as before, we use an indicator for those who worked for the Pinochet regime, and also 
two indicators for different military and civilian to explore heterogeneous effects.

Table 4 presents results. In column 1, we observe a statistically significant decrease of 11 percentage points in the probability that dictatorship collaborators were working as business elite in democracy. Column 2 reveals that this decrease is mostly driven by military collaborators. Columns 3 and 4 use the total number of boards as dependent variable and a similar picture arises, but now the military and civilians appear to work at fewer boards in democracy. Columns 5-8 examine their work in high-positions and the same pattern emerges. All in all, this table suggests that dictatorship collaborators left their positions in the business elite after democratization.

Figure 2 complements previous results and presents estimates of a flexible version of regression equation (2) to test for parallel trends and dynamic adjustments. The estimated coefficients show that our findings are robust and not driven by a particular year. Moreover, even though we unfortunately have data for only two years before 1988 , there is reassuringly no statistically significant difference in board participation across collaborators and other board members before democratization.

The appendix shows that the differential work of collaborators in the business elite after dictatorship is a robust finding. We obtain similar results when we restrict attention to individuals working only in high-positions (see Table A.1) and when we control for firm-level variables (indicator for privatized firms, board size) and individual-level characteristics (age, degree) interacted with an indicator for the period after 1988 (see Tables A.2 and A.3). Results are also robust when we collapse our annual panel to three periods (dictatorship, transition, and democracy) to deal with serially correlated outcomes (Bertrand et al. 2004, see Table A.5).

A word of caution is necessary to interpret these results. Even though collaborators exited boards after dictatorship, this finding does not necessarily implies they suffered an economic loss. It is certainly possible that they became employed in a different sector of the economy in smaller firms. Unfortunately, there is no way of tracking the complete labor history of individuals with our data. However, because board members are responsible for managing the largest firms in the economy, we believe 
exiting these boards does imply a decrease in the economic power of this group. In fact, when combined with the compensation patterns we describe in the next section, we believe the evidence suggests a significant economic loss of collaborators.

\subsection{Board compensation after democratization}

An additional margin that may have affected collaborators after the transition is their compensation. Did dictatorship collaborators experience changes in their board compensation after democratization? To answer this question, we estimate the following regression equation using individuals who remained working after 1988:

$$
\log \left(w_{i j k t}\right)=\gamma_{1}\left(\mathrm{C}_{i} \times \text { Transition }_{t}\right)+\gamma_{2}\left(\mathrm{C}_{i} \times \text { Democracy }_{t}\right)+\xi_{i j}+\zeta_{k t}+v_{i j k t}
$$

where $w_{i j k t}$ is the annual compensation of individual $i$ in firm $j$, industry $k$, and year $t$. The remaining variables are defined as in equation (2). The error term $v_{i j k t}$ is again clustered at both the individual and firm levels.

Before estimating equation (3), we estimate the same equation but omitting the transition period because these years were of an arguably different nature as it was known that Pinochet was leaving power. Columns 1 and 2 in Table 5 present these estimates. When compared to the dictatorship period, collaborators experienced, on average, a decrease of 67 percent in their board compensation in democracy, which can be decomposed in a decline in the compensation of the military ( 83 percent) and civilians who participated in the regime (65 percent). Taken together, these two columns show that collaborators suffered a significant decrease in their compensation in democracy when compared to dictatorship.

We present estimates of equation (3) in columns 3 and 4 . In contrast to the patterns in democracy, we observe an increase of $5^{1}$ percent in the compensation of collaborators during transition. This increase is consistent with their connection to the regime being valuable to the firm in that period - González and Prem (2017) show that political links allowed firms to acquire credit from state banks during transition - and is 
more pronounced among the military ( 78 percent versus 40 percent). The last column in this table presents compensation differences between the transition and the democracy periods. These columns reveal that the decline in the board compensation of collaborators in democracy is uniform across type of collaboration and of significant economic magnitude.

Overall, we observe an increase in the board compensation of collaborators in the transition period and a decrease in their compensation in democracy. Recall that these variations represent deviations from the average compensation in dictatorship. To get a sense of their magnitude, it is useful to compare these changes to the returns of education in dictatorship. While the compensation increase in transition corresponds to approximately the average return of graduating from college, the decrease in democracy is equivalent to graduating from high-school. We conclude that the observed variations after 1988 are economically meaningful. ${ }^{13}$

\subsection{Productivity versus favoritism}

Theoretically there are at least two mechanisms that can explain the existence of a work premium for collaborators in dictatorship, productivity and favoritism. On one hand, collaborators may have characteristics that are unobserved by the econometrician but observed by firms and these make them more productive, which translates into higher compensation. On the other hand, a dictatorship may show favoritism for firms with collaborators, increasing collaborator's from the perspective of the firm.

We argue that previous results are inconsistent with a productivity story and are more consistent with a favoritism mechanism. If collaborators were more productive because of their skills, then we should observe them working on the same number of boards and with the same compensation in democracy, because skills are relatively fixed over time. At the same time, because military collaborators had arguably dif-

\footnotetext{
${ }^{13}$ These variations in board compensation are also robust when we control for firm-level variables (indicator privatized firms, board size) and individual-level characteristics (age, university degree) interacted with an indicator for the period after dictatorship (see Table A.4).
} 
ferent managerial skills than civilian collaborators, thus we should observe heterogeneous effects across both groups after democratization. However, we do not observe any of the implications derived from a higher productivity mechanism.

In contrast to the previous argument, a preferential treatment from the regime to collaborators creates rents for firms and individuals in a dictatorship, implying that firms should reoptimize their board composition in the way we observe empirically. To test more directly for a favoritism mechanism, we now look at the wages of military personnel before, during, and after dictatorship.

\section{The Wage Premium of Military Personnel}

To shed some light on the mechanism behind previous findings, we study the wages of military personnel. The motivation is that the existence of a wage premium among a group of people, who worked closely with the Pinochet regime but was not part of any firm, implies that the regime was indeed treating their allies differently. We cannot, however, conclude in a definitive way that a preferential treatment in the military proves the existence of preferential treatment among board members who had collaborated with Pinochet. Nevertheless, taken together, results suggest that a preferential mechanism is relatively more important than productivity in explaining our findings.

\subsection{Historical background}

The military origins of Pinochet dictatorship suggest that individuals working in the armed forces might have experienced a differential treatment between 1973 and 1990. In Chile, the wage received by the military personnel is established by a set of laws. Recently, 150 classified laws and decrees enacted in the 1970s and 1980s were released to the public. These documents reveal how the Pinochet regime was able to trans-

fer 442 million U.S. dollars from the Central Bank and the General Treasure to the 
armed forces (Dinges and Escalante, 2010b). ${ }^{14}$ No official reason has been given to justify the monetary transfer. ${ }^{15}$ Classified decrees enacted in 1976 (Decrees $\mathrm{N}^{0}{ }^{1589}$ 90) mentioned that some of the monetary transfers were to be used to pay "bonuses" to the military personnel. This fact leads us to hypothesize that the Pinochet regime intended to increase the wages of the armed forces after 1973.

Theoretically there are at least two reasons why we think wage increasing could be an optimal strategy. First, in a model where the majority of individuals in the dictator's network work in the armed forces - and assuming the dictator prefers his social network to have higher utility - increasing military wages is an optimal strategy. This is favoritism consistent with the findings in Hodler and Raschky (2014). Second, if the armed forces provide a threat to the stability of the dictator, then increasing their wages could be seen as a potentially useful strategy to decrease the probability of political unrest. Since Pinochet enjoyed considerable support among the armed forces, the former strategy is more likely to be relevant in this context.

\subsection{Data and econometric strategy}

Let the wage premium of military personnel $\omega_{t}$ to be defined as the logarithm of wages of individuals working in the armed forces, minus the logarithm of wages of individuals working in the public sector, the comparison group. Using the Occupation Survey, we estimate this wage premium for the period 1957-2010 and present it in Figure 3. There is a large increase in the wage premium of military personnel after the 1973 coup d'etat. The increase in the wage premium stopped briefly at the time of the 1982 economic crisis, and disappeared with the arrival of the new democratic

\footnotetext{
${ }^{14}$ For example, instead of $10 \%$ of copper sales, the main revenue of the Chilean state, Decree 984 established a minimum of 90 million U.S. dollars in transfers from copper sales to the armed forces. In 1985, Law 18.445 doubled this minimum. In 1987, the regime established that investments from copper sales needed to be approved by the leaders of the armed forces (Dinges and Escalante, 2010a).

${ }^{15}$ The conflict between Chile and Argentina over a territory known as the Beagle Channel created a military tension that might justify some of the transfers. However, monetary transfers to the armed forces continued even after the Act of Montevideo in 1979 (Reserved Decree Law No 3527 in 1980 and Secret Law $\mathrm{N}^{0} 18.090$ in 1981), in which both countries renounced the use of force.
} 
government in 1990. The wage premium remains large after the 1988 plebiscite.

In order to statistically test if wages were unusually high during Pinochet dictatorship, we estimate the difference in wages of military personnel and workers in the public sector over time using the following regression equation:

$$
\log \left(w_{i t}\right)=\beta \cdot\left(A_{i t} T_{t}\right)+\delta A_{i t}+\gamma X_{i}+\rho T_{t}+v_{i t}
$$

where $w_{i t}$ is the annual wage of person $i, A_{i t}$ is an indicator variable for individuals working in the armed forces, $T_{t}$ is a set of indicator variables for political periods, and $X_{i}$ is a matrix of individual characteristics (education categories, age, and age square). The error term $v_{i t}$ is assumed to have mean zero and it is clustered at the year level. The coefficients of interest are in the vector $\beta$, and measure the changes in the wage premium of the military personnel in different political periods. We consider the following political periods: before Frei's government (1957-1965, the omitted category), Frei (1965-1970), Allende (1970-1973), Pinochet regime (1973-1990), and after dictatorship (1990-2010).

Column I presents estimates of equation (4). Two facts emerge from this column. First, during the Pinochet regime the wages of the military personnel more than doubled. Second, in democracy, the wage of the military remained 20 percent larger than the wages of workers in the public sector. In addition, columns 2 and 3 in Table 6 present results of a linear regression of $(\log )$ wages on an indicator variable for individuals in the armed forces using data for the years 1985-1988 and years 1990-1993 respectively. The coefficients show again that military personnel earned twice the wage of workers in the public sector and only 20 percent more during democracy. In column 4, we present results of estimating equation (4) but only in the period 1985-1993. Consistent with the estimates in previous columns, we again observe a significant decrease in the wages of military personnel in democracy. ${ }^{16}$

\footnotetext{
${ }^{16}$ Note that, consistent with Rodrik (1999), the wages of all workers in the public sector are significantly higher in democracy. This means that, in nominal terms, the wage of military personnel grew more slowly.
} 


\section{Conclusion}

What is the value of political capital for individuals providing political connections? We have shown that board members who had previously collaborated with the Pinochet dictatorship in Chile, worked on the boards of more firms, in higher positions, and earned a higher compensation than their fellow board members before Chile's transition to democracy. These results suggest the existence of an economically meaningful premium for individuals with political capital. This premium disappeared after democratization, when the political capital of collaborators depreciated, suggesting it is not related to unobservable higher skill levels. To gain further insights on the mechanism, we have presented suggestive evidence of favoritism by showing a large increase in military personnel wages during the Pinochet regime.

Our results complement the existing literature by showing that individuals providing connections between the state and the business world are compensated by it. The result of this is by no means a corollary of an increase in firm value due to the existence of political connections. Indeed, it is certainly possible that firms extract the entirety of the rents created by political links, leaving individuals with political capital with nothing. One hypothesis is that how rents are divided between firms and individuals providing the links, is the consequence of a bargaining problem. Our analysis suggests that individuals with political capital have some bargaining power to extract rents in the context of a dictatorship.

If the existence of links between the state and the business world creates rents to be divided between firms and individuals, then our results need to be interpreted with caution when taken outside of the context of the Pinochet dictatorship. For example, the value of political capital may be different in dictatorships and democracies. Indeed, a very simple model in which more individuals work in the state apparatus in a democracy - when compared to the same number in dictatorship - can easily predict that firms receive a bigger share of the rents created by political connections because individuals providing the links are relatively abundant. In the same spirit, early and 
consolidated democracies may also affect the bargaining problem differently and the size of rents that are extracted can change how it is divided. Additional estimates of wage premiums arising from political connections are necessary to understand how rents are divided among firms and individuals.

\section{References}

Acemoglu, D., Johnson, S., Kermani, A., Kwak, J., and Mitton, T. (2016). The value of connections in turbulent times: evidence from the United States. Journal of Financial Economics, 121(2):368-391.

Adams, R. B., Hermalin, B. E., and Weisbach, M. S. (2010). The role of boards of directors in corporate governance: a conceptual framework and survey. Journal of Economic Literature, 48(1):58-107.

Amore, M. D. and Bennedsen, M. (2013). The value of local political connections in a low-corruption environment. Journal of Financial Economics, 110(2):387-402.

Benmelech, E. and Frydman, C. (2015). Military CEOs. Journal of Financial Economics, 117(1):43-59.

Bertrand, M., Duflo, E., and Mullainathan, S. (2004). How much should we trust differences-in-differences estimates? Quarterly Journal of Economics, 119(1):249-275.

Blanes i Vidal, J., Draca, M., and Fons-Rosen, C. (2012). Revolving door lobbyists. American Economic Review, 102(7):3731-48.

Boas, T. C. (2015). Voting for democracy: campaign effects in Chile's democratic transition. Latin American Politics and Society, 57(2):67-90.

Carlyle, E. (2013). Meet chemicals billionaire Julio Ponce Lerou, former son-in-law of chilean dictator Augusto Pinochet. Forbes Magazine.

Cavallo, A., Salazar, M., and Sepúlveda, O. (2011). La Historia Oculta del Régimen Militar: Memoria de una Época 1973-1988. Uqbar editores.

Centro de Estudios Públicos (1992). "El Ladrillo": Bases de la Política Económica del Gobierno Militar Chileno. Centro de Estudios Públicos.

Cingano, F. and Pinotti, P. (2013). Politicians at work: the private returns and social costs of political connections. Journal of the European Economic Association, 11(2):433465 . 
Claessens, S., Feijen, E., and Laeven, L. (2008). Political connections and preferential access to finance: the role of campaign contributions. Journal of Financial Economics, 88(3):554-580.

Cohen, L., Frazzini, A., and Malloy, C. (2008). The small world of investing: board connections and mutual fund returns. Journal of Political Economy, 116(5):951-979.

Colonnelli, E. and Prem, M. (2017). Corruption and firms: evidence from randomized audits in Brazil. Working Paper.

Dinges, J. and Escalante, J. (2010a). Las 150 leyes secretas de la dictadura. Archivo Chile.

Dinges, J. and Escalante, J. (2010b). Mediante leyes secretas Pinochet obtuvo us\$ millones desde el Banco Central y la Tesorería. Archivo Chile.

Faccio, M. (2006). Politically connected firms. American Economic Review, 96(1):369386.

Faccio, M., Masulis, R. W., and McConnell, J. J. (2006). Political connections and corporate bailouts. Journal of Finance, 61(6):2597-2635.

Ferguson, T. and Voth, H.-J. (2008). Betting on Hitler: the value of political connections in Nazy Germany. Quarterly Journal of Economics, 123(1):101-137.

Fisman, D., Fisman, R., Galef, J., Khurana, R., and Wang, Y. (2012). Estimating the value of political connections to vice-president Cheney. The B.E. Journal of Economic Analysis and Policy, 13(3).

Fisman, R. (2001). Estimating the value of political connections. American Economic Review, 91(4):1095-1102.

Fisman, R., Schulz, F., and Vig, V. (2014). The private returns to public office. Journal of Political Economy, 122(4):806-862.

Fisman, R. and Wang, Y. (2015). The mortality cost of political connections. Review of Economic Studies, 82(4):1346-1382.

Gagliarducci, S. and Manacorda, M. (2014). Politics in the family: nepotism and the hiring decisions of Italian firms.

González, F. and Prem, M. (2017). Losing your dictator: firms during political transition. Working Paper.

González, F. and Prem, M. (2018). Can television bring down a dictator? Evidence from Chile's "No" campaign. Journal of Comparative Economics.

Hodler, R. and Raschky, P. A. (2014). Regional favoritism. Quarterly Journal of Economics, 129(2):995-1033. 
Hsieh, C.-T., Miguel, E., Ortega, D., and Rodriguez, F. (2011). The price of political opposition: evidence from venezuela's maisanta. American Economic Journal: Applied Economics, 3(2):196-214.

Huneeus, C. (2000). Technocrats and politicians in an authoritarian regime. The 'ODEPLAN Boys' and the 'Gremialists' in Pinochet's Chile. Journal of Latin American Studies, 32(2):461-501.

Jayachandran, S. (2006). The Jeffords effect. Journal of Law and Economics, 49(2):397-425.

Kaplan, A. (2001). The Collaborator: The Trial and Execution of Robert Brasillach. University of Chicago Press.

Khwaja, A. I. and Mian, A. (2005). Do lenders favor politically connected firms? Rent provision in an emerging financial market. Quarterly Journal of Economics, 120(4):1371-1411.

Klein, N. (2008). The Shock Doctrine: The Rise of Disaster Capitalism. Picador.

Kostovetsky, L. (2015). Political capital and moral hazard. Journal of Financial Economics, 116(1):144-159.

Lefort, F. and Urzúa, F. (2008). Board independence, firm performance and ownership concentration: evidence from Chile. Journal of Business Research, 61(6):615-622.

Mönckeberg, M. O. (2015). El Saqueo de los Grupos Económicos al Estado Chileno. De Bolsillo.

Rodrik, D. (1996). Understanding economic policy reform. Journal of Economic Literature, 34(1):9-41.

Rodrik, D. (1999). Democracies pay higher wages. The Quarterly Journal of Economics, 114(3):707-738.

Salazar, M. (1995). Contreras: Historia de un Intocable. Grijalbo.

Salazar, M. (2015). Todo Sobre Julio Ponce Lerou: De Yerno de Pinochet a Millonario. Uqbar.

Schwartz-Ziv, M. and Weisbach, M. S. (2013). What do boards really do? Evidence from minutes of board meetings. Journal of Financial Economics, 108(2):349-366.

Spooner, M. H. (1999). Soldiers in a Narrow Land: The Pinochet Regime in Chile. University of California Press.

Treisman, D. (2017). Democracy by mistake. NBER Working Paper 23944.

Woloch, I. (2002). Napoleon and His Collaborators: The Making of a Dictatorship. W. W. Norton and Company. 
Figure 1: Wage distributions during the dictatorship

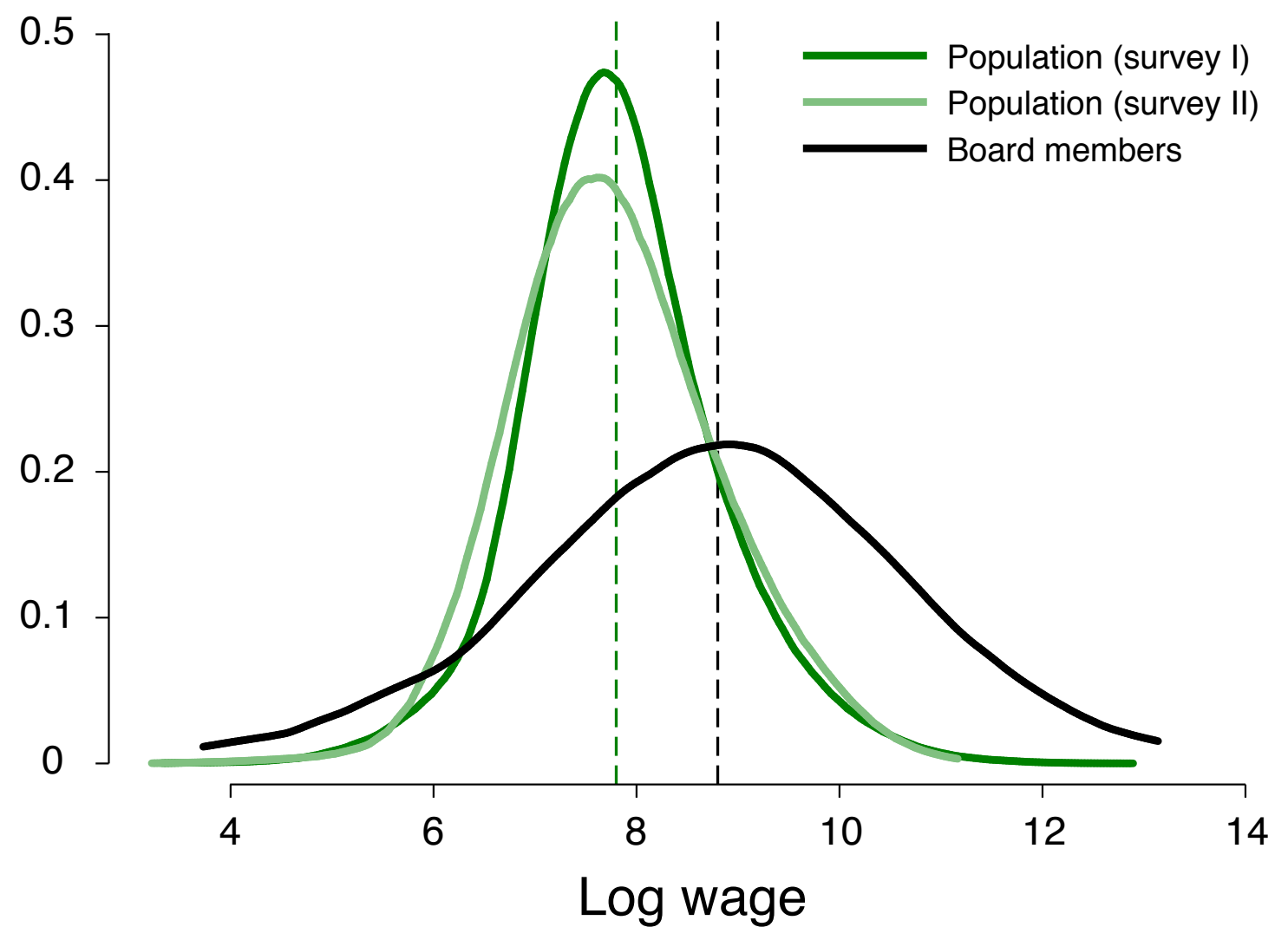

Notes: Distribution of annual (log) wages in 1987 (in 2000 U.S. dollars) using three different data sets. Survey I: National representative survey (Encuesta Nacional de Caracterización Socioeconómica) conducted by the Ministry of Social Development. Density calculation uses data on 30,874 individuals with positive income. Survey II: Oldest labor survey in Chile, conducted by the University of Chile, containing labor information on random households in Santiago, capital of Chile. Board members: Own construction based on financial statements collected by the Superintendencia de Valores y Seguros (Securities and Exchange Commission is the U.S. equivalent). The mean wage of executive directors lies at the 88th percentile of the wage distribution in Surveys I and II. 


\section{Figure 2: Dictatorship collaborators after democratization}

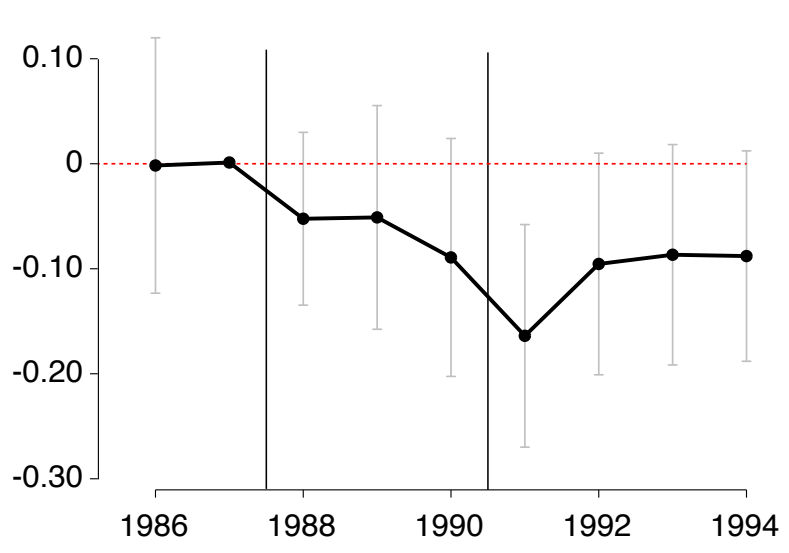

(a) Works as board member

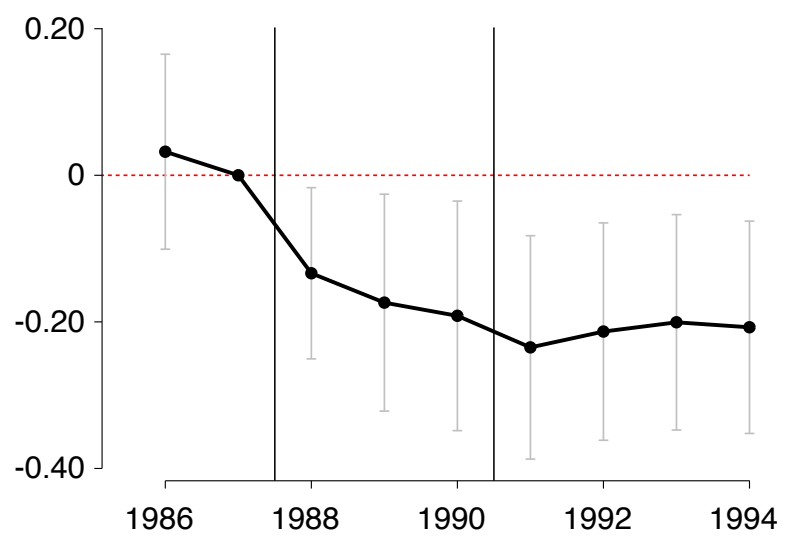

(c) Works - high position

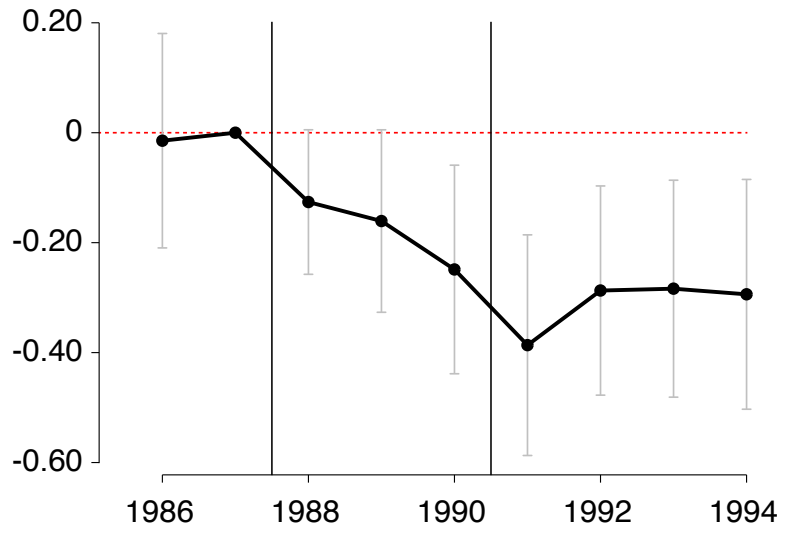

(b) Number of boards

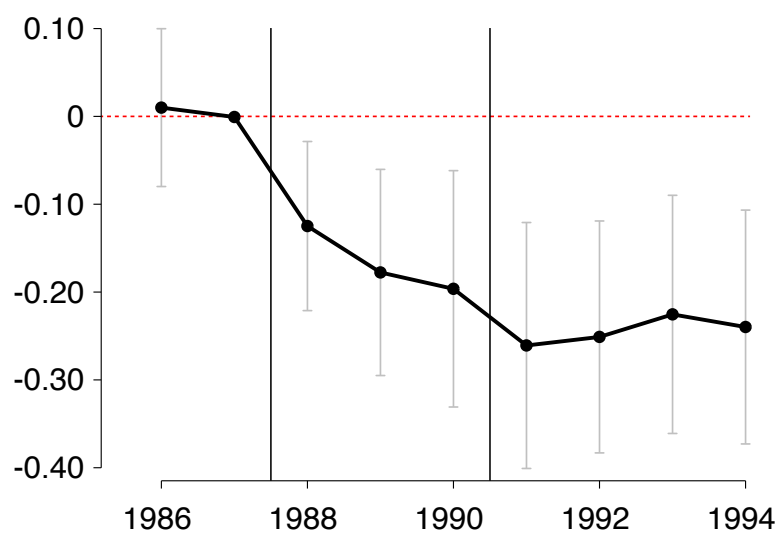

(d) Boards - high position

Notes: This figure shows a dynamic version of equation (2). Panel A shows the results for a dummy of working, panel B for the number of jobs as board member, panel C shows a dummy for those working as president or vice-president of the board, while panel $\mathrm{D}$ shows the number of jobs as president or vice-president of the board. In grey we present the $95 \%$ confidence intervals. 
Figure 3: Wage premium of military personnel

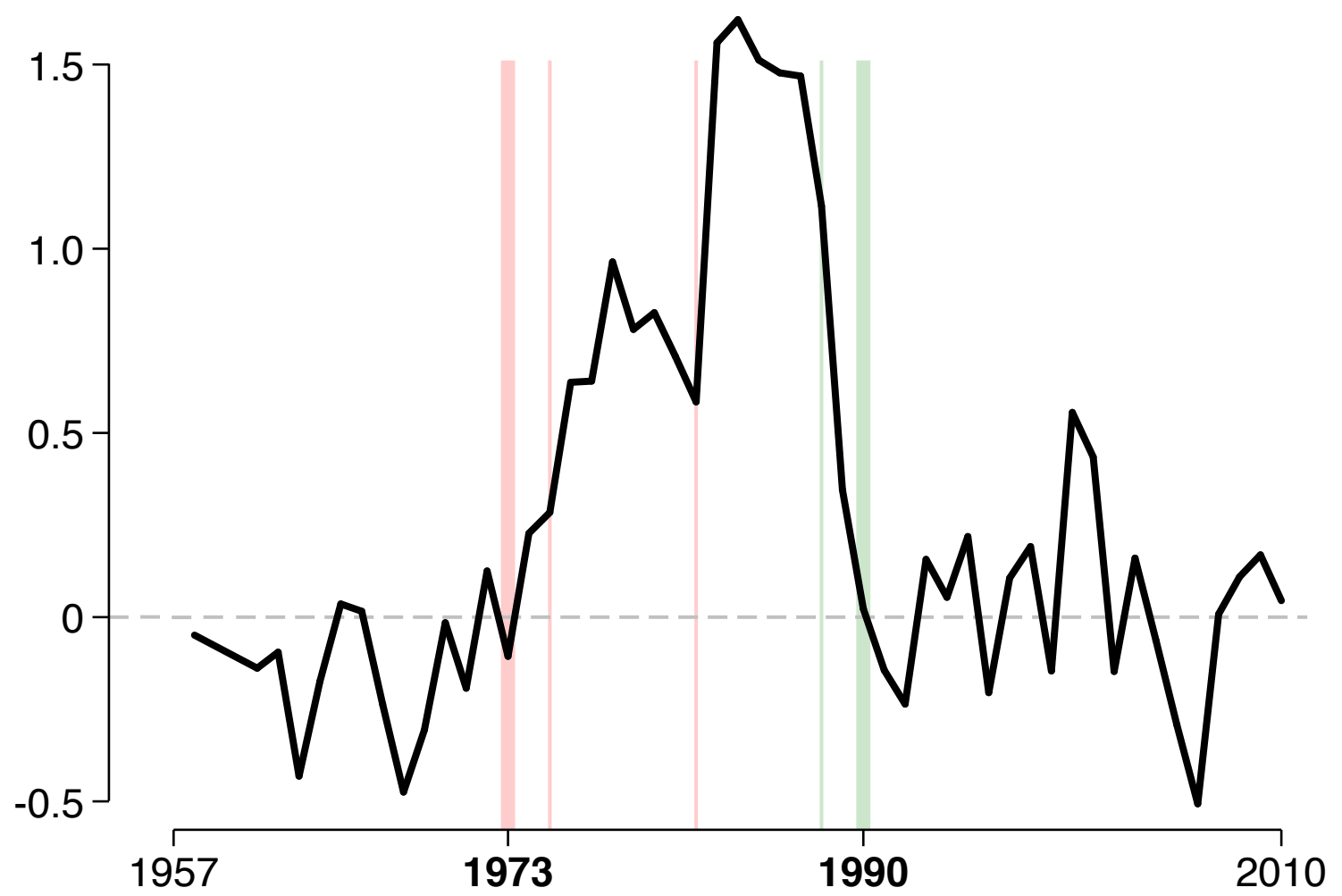

Notes: This figure presents the wage premium of military personnel in the period 1957-2010. The wage premium in year $t$ is defined as:

$$
\omega_{t} \equiv \log \left(w_{t}^{A F}\right)-\log \left(w_{t}^{S}\right)
$$

where $w_{t}^{A F}$ is the average wage of military personnel and $w_{t}^{S}$ is the average wage of workers in the public sector. Thick vertical lines denote the beginning (1973) and end (1990) of the Pinochet regime. Thin vertical lines denote the year political reforms began (1975), the 1982 economic crisis, and the 1988 plebiscite. Source: Occupation Survey, described in section 3.2. 
Table 1: Summary statistics of board members during the dictatorship

\begin{tabular}{|c|c|c|c|}
\hline \multirow[b]{2}{*}{ Work as board members } & $\frac{\text { Mean }}{(1)}$ & $\frac{\text { St. Dev. }}{(2)}$ & $\frac{\text { Observations }}{(3)}$ \\
\hline & & & \\
\hline Number of boards per year & 1.16 & 0.89 & 2,222 \\
\hline Number of high positions per year & 0.21 & 0.56 & 2,222 \\
\hline Number of boards & 2.33 & 1.63 & 1,111 \\
\hline Annual compensation (USD) & 32,519 & 58,695 & 1,044 \\
\hline \multicolumn{4}{|l|}{ Dictatorship collaborators } \\
\hline Indicator collaborator & 0.08 & 0.29 & 1,111 \\
\hline Indicator military & 0.02 & 0.14 & 1,111 \\
\hline Indicator civilian & 0.06 & 0.12 & 1,111 \\
\hline \multicolumn{4}{|l|}{ Characteristics of board members } \\
\hline Indicator degree in business & 0.35 & 0.48 & 1,030 \\
\hline Indicator degree in engineering & 0.27 & 0.45 & 1,030 \\
\hline Indicator degree in law & 0.20 & 0.40 & 1,030 \\
\hline Studied at Catholic University & 0.27 & 0.45 & 322 \\
\hline Studied at University of Chile & 0.49 & 0.50 & 322 \\
\hline
\end{tabular}

Notes: This table presents summary statistics for board members in dictatorship. Number of high positions per year is defined as the total number of jobs as president or vicepresident in each year. Annual compensation in USD is the total compensation as a board member in 2000 USD. 
Table 2: Firm-level differences by collaboration status

\begin{tabular}{|c|c|c|c|c|c|}
\hline & $\begin{array}{c}\text { All } \\
\text { firms }\end{array}$ & $\begin{array}{l}\text { Firms with } \\
\text { at least one } \\
\text { collaborator }\end{array}$ & $\begin{array}{c}\text { Firms } \\
\text { without } \\
\text { collaborators }\end{array}$ & $\begin{array}{l}\text { Difference } \\
(2)-(3)\end{array}$ & $\begin{array}{c}p \text {-value } \\
\text { of difference }\end{array}$ \\
\hline & (1) & (2) & (3) & (4) & (5) \\
\hline Firms with board data & 186 & 65 & 121 & - & - \\
\hline Firms with board and balance sheet data & 154 & 55 & 99 & - & - \\
\hline Board size & 6.9 & 7.6 & 6.5 & 1.1 & 0.01 \\
\hline Logarithm of assets & 16.0 & 17.4 & 15.2 & 2.2 & 0.00 \\
\hline Leverage & 0.52 & 0.53 & 0.51 & 0.02 & 0.85 \\
\hline Return over assets & 0.19 & 0.12 & 0.24 & -0.12 & 0.04 \\
\hline Indicator for exporting & 0.37 & 0.34 & 0.40 & -0.06 & 0.57 \\
\hline Years since foundation & 46.4 & 47.8 & 45.6 & 2.2 & 0.67 \\
\hline Years with compensation data & 5.0 & $5 \cdot 7$ & 4.7 & 1.0 & 0.09 \\
\hline
\end{tabular}

Notes: This table shows average differences for firms with and without dictatorship collaborators. Columns (1), (2), and (3) show averages for the whole sample, for connected and unconnected firms, column (4) presents the difference between columns (2) and (3), and column (5) presents the p-value of a two-way average test. 
Table 3: The work premium of dictatorship collaborators

\begin{tabular}{|c|c|c|c|c|c|c|c|c|}
\hline Dependent variable: & $\begin{array}{r}\mathrm{Nu} \\
\text { boarc } \\
\mathrm{p}\end{array}$ & $\begin{array}{l}\text { ber of } \\
\text { ositions } \\
\text { year }\end{array}$ & $\begin{array}{r}\text { Nun } \\
\text { high } \mathrm{f} \\
\text { per }\end{array}$ & $\begin{array}{l}\text { per of } \\
\text { sitions } \\
\text { year }\end{array}$ & & mpensa & tion (US & \\
\hline & $(1)$ & $(2)$ & (3) & (4) & (5) & (6) & $(7)$ & $(8)$ \\
\hline Dictatorship collaborator & $\begin{array}{l}0.18^{* *} \\
(0.08)\end{array}$ & & $\begin{array}{c}0.24^{* * *} \\
(0.06)\end{array}$ & & $\begin{array}{l}3,971^{*} \\
(2,418)\end{array}$ & & $\begin{array}{l}5,596^{* *} \\
(2,745)\end{array}$ & \\
\hline Military & & $\begin{array}{c}0.10 \\
(0.12)\end{array}$ & & $\begin{array}{c}0.15 \\
(0.09)\end{array}$ & & $\begin{array}{l}4,110^{*} \\
(2,182)\end{array}$ & & $\begin{array}{c}3,362 \\
(2,095)\end{array}$ \\
\hline Civilian & & $\begin{array}{l}0.21^{* *} \\
(0.10)\end{array}$ & & $\begin{array}{c}0.28^{* * *} \\
(0.08)\end{array}$ & & $\begin{array}{c}3,915 \\
(3,033)\end{array}$ & & $\begin{array}{c}5,421 \\
(7,524)\end{array}$ \\
\hline Board members & 1,111 & 1,111 & 1,111 & 1,111 & 545 & 545 & 394 & 394 \\
\hline Observations & 2,222 & 2,222 & 2,222 & 2,222 & 679 & 679 & 521 & 521 \\
\hline Mean of dependent variable & 1.16 & 1.16 & 0.21 & 0.21 & 30,192 & 30,192 & 32,323 & 32,323 \\
\hline Year fixed effects & $\mathrm{x}$ & $\mathrm{x}$ & $\mathrm{x}$ & $\mathrm{x}$ & & & & \\
\hline Firm fixed effects & & & & & $x$ & $x$ & $x$ & $x$ \\
\hline Individual Controls & & & & & & & $x$ & $x$ \\
\hline
\end{tabular}

Notes: Individual controls include an indicator for board members with a university degree in law, business and economics, and engineering. Robust standard errors are clustered at the individual level. Significance level: ${ }^{* * *} p<0.01$, ** $p<0.05, * p<0.1$. 
Table 4: Dictatorship collaborators after democratization

\begin{tabular}{|c|c|c|c|c|c|c|c|c|}
\hline & \multicolumn{4}{|c|}{ Works in board } & \multicolumn{4}{|c|}{ Works in high-position at board } \\
\hline & \multicolumn{2}{|c|}{ Indicator } & \multicolumn{2}{|c|}{ Number of boards } & \multicolumn{2}{|c|}{ Indicator } & \multicolumn{2}{|c|}{ Number of boards } \\
\hline & (1) & (2) & (3) & $(4)$ & (5) & (6) & (7) & (8) \\
\hline Collaborator $\times$ Democracy & $\begin{array}{c}-0.106^{* *} \\
(0.044)\end{array}$ & & $\begin{array}{c}-0.226^{* * *} \\
(0.083)\end{array}$ & & $\begin{array}{c}-0.138^{* * *} \\
(0.042)\end{array}$ & & $\begin{array}{c}-0.227^{* * *} \\
(0.062)\end{array}$ & \\
\hline$\times$ Transition & $\begin{array}{l}-0.050 \\
(0.050)\end{array}$ & & $\begin{array}{l}-0.111 \\
(0.080)\end{array}$ & & $\begin{array}{c}-0.094^{* *} \\
(0.038)\end{array}$ & & $\begin{array}{c}-0.151^{* * *} \\
(0.051)\end{array}$ & \\
\hline Military $\times$ Democracy & & $\begin{array}{c}-0.246^{* * *} \\
(0.077)\end{array}$ & & $\begin{array}{c}-0.377^{* * *} \\
(0.139)\end{array}$ & & $\begin{array}{c}-0.179^{* *} \\
(0.076)\end{array}$ & & $\begin{array}{c}-0.252^{* *} \\
(0.123)\end{array}$ \\
\hline$\times$ Transition & & $\begin{array}{c}-0.15^{* *} \\
(0.073)\end{array}$ & & $\begin{array}{c}-0.249^{* *} \\
(0.119)\end{array}$ & & $\begin{array}{l}-0.115^{*} \\
(0.065)\end{array}$ & & $\begin{array}{l}-0.162 \\
(0.098)\end{array}$ \\
\hline Civilian $\times$ Democracy & & $\begin{array}{l}-0.063 \\
(0.046)\end{array}$ & & $\begin{array}{l}-0.172^{*} \\
(0.099)\end{array}$ & & $\begin{array}{c}-0.126^{* * *} \\
(0.045)\end{array}$ & & $\begin{array}{c}-0.218^{* * *} \\
(0.071)\end{array}$ \\
\hline$\times$ Transition & & $\begin{array}{c}-0.017 \\
(0.058)\end{array}$ & & $\begin{array}{l}-0.061 \\
(0.097)\end{array}$ & & $\begin{array}{l}-0.087^{* *} \\
(0.039)\end{array}$ & & $\begin{array}{c}-0.148^{* *} \\
(0.059)\end{array}$ \\
\hline Board members & 1,111 & 1,111 & 1,111 & 1,111 & 1,111 & 1,111 & 1,111 & 1,111 \\
\hline Observations & 13,698 & 13,698 & 9,999 & 9,999 & 13,698 & 13,698 & 9,999 & 9,999 \\
\hline R-squared & 0.605 & 0.606 & 0.789 & 0.789 & 0.734 & 0.734 & 0.813 & 0.813 \\
\hline Mean of dependent variable & 0.847 & 0.847 & 1.150 & 1.150 & 0.142 & 0.142 & 0.192 & 0.192 \\
\hline Fixed effects & $\mathrm{x}$ & $\mathrm{x}$ & $\mathrm{x}$ & $x$ & $x$ & $x$ & $\mathrm{x}$ & $\mathrm{x}$ \\
\hline
\end{tabular}

Notes: All specifications include firm-board member fixed effect, industry-transition, and industry-democracy fixed effects. The mean of the dependent variable is computed based on non-collaborators during the dictatorship period. Robust standard errors are doubly clustered by board member and firm. Significance level: ${ }^{* * *} p<0.01,{ }^{* *} p<0.05$, * $p<0.1$. 


\section{Table 5: Compensation of collaborators after democratization}

\begin{tabular}{|c|c|c|c|c|c|}
\hline & \multicolumn{2}{|c|}{ Two periods } & \multicolumn{2}{|c|}{ Three periods } & \multirow{2}{*}{$\begin{array}{c}\text { Difference } \\
\text { (democracy - transition) } \\
(5)\end{array}$} \\
\hline & (1) & (2) & (3) & (4) & \\
\hline Collaborator $\times$ Democracy & $\begin{array}{l}-0.667^{*} \\
(0.349)\end{array}$ & & $\begin{array}{l}-0.497 \\
(0.319)\end{array}$ & & $-1.00^{* *}$ \\
\hline$\times$ Transition & & & $\begin{array}{l}0.506^{* *} \\
(0.200)\end{array}$ & & \\
\hline Military $\times$ Democracy & & $\begin{array}{c}-0.833^{* * *} \\
(0.222)\end{array}$ & & $\begin{array}{c}-0.101 \\
(0.263)\end{array}$ & $-0.88^{* * *}$ \\
\hline$\times$ Transition & & & & $\begin{array}{l}0.782^{* *} \\
(0.337)\end{array}$ & \\
\hline Civilian $\times$ Democracy & & $\begin{array}{l}-0.654^{*} \\
(0.366)\end{array}$ & & $\begin{array}{l}-0.573^{*} \\
(0.337)\end{array}$ & $-0.96^{* *}$ \\
\hline$\times$ Transition & & & & $\begin{array}{c}0.397 \\
(0.250)\end{array}$ & \\
\hline Board member-firm & 430 & 430 & 430 & 430 & \\
\hline Observations & 550 & 550 & 1,135 & 1,135 & \\
\hline Board member-firm fixed effects & $\mathrm{x}$ & $\mathrm{x}$ & $\mathrm{x}$ & $\mathrm{x}$ & \\
\hline Industry-period fixed effects & $x$ & $x$ & $x$ & $x$ & \\
\hline
\end{tabular}

Notes: Transition is a dummy for the years 1988 to 1990, while Democracy is a dummy for the years post 1990. Column (5) presents a test for the difference between the transition and the democracy coefficients, in this case the p-value is presented in parenthesis. Robust standard errors are doubly clustered at the board member and firm level. Significance level: ${ }^{* *} p<0.01,{ }^{* *} p<0.05,{ }^{*} p<0.1$. 
Table 6: Wage premium of military personnel

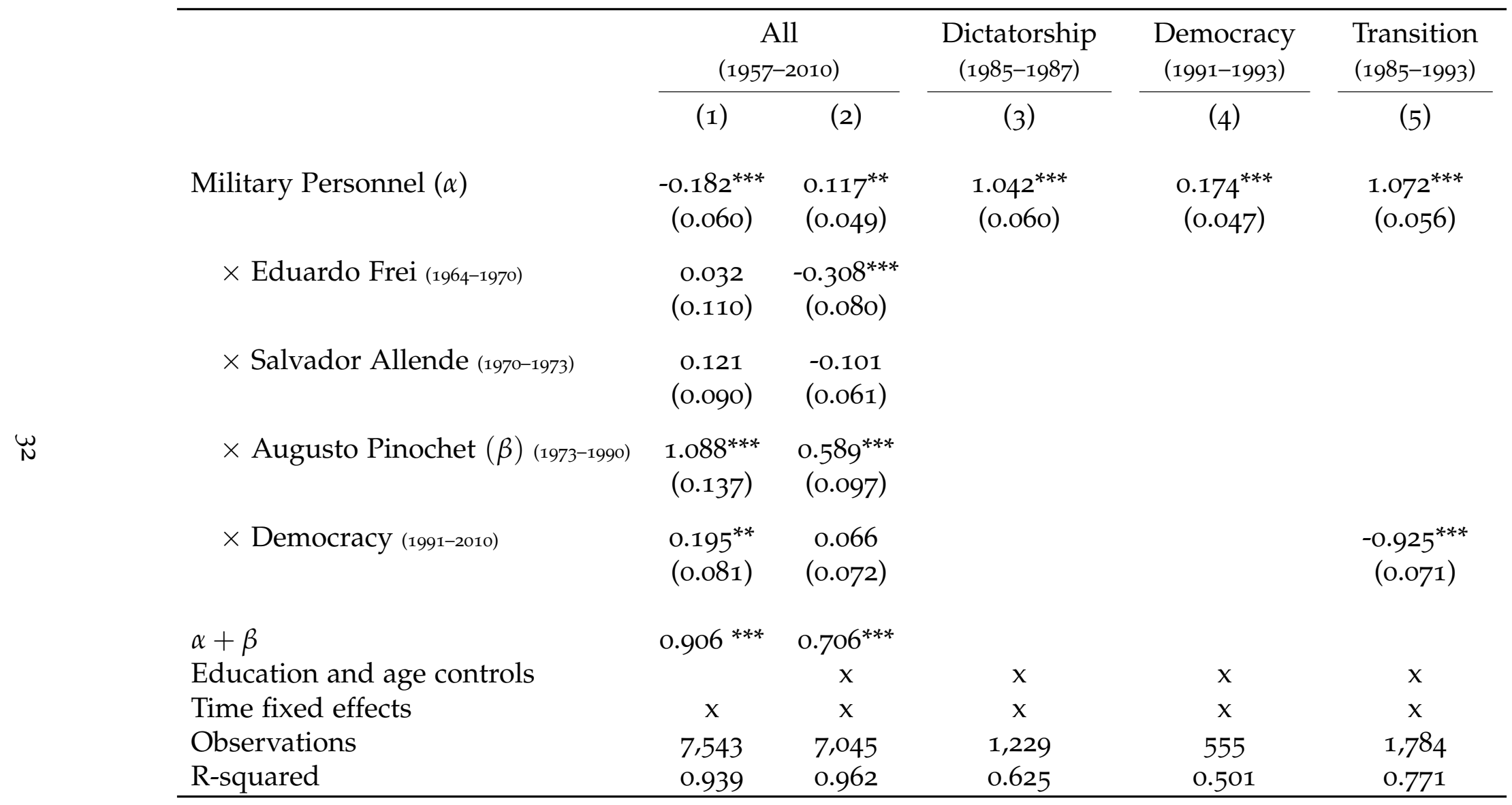

Notes: This table shows the wage premium between employees in the armed forces and other public sector employees. The omitted category corresponds to public employees not in the armed forces. The dependent variable is the logarithm of wages. Military Personnel is a dummy for employees in the armed forces. The time dummies are constructed for each of the presidents between 1964 and 1990 and then after dictatorship. The omitted years are the ones from 1964 to 1957. Education controls include a dummy for finishing primary, secondary, university, technical education. Age controls include age and age squared. All specifications include year fixed effects. In columns 1-2, we present standard errors clustered at the year level in parentheses. In columns 3-5, we present robust standard errors in parentheses. Significance level: ${ }^{* *} p<0.01,{ }^{* *} p<0.05,{ }^{*} p<0.1$. 


\section{For Online Publication}

The Value of Political Capital: Dictatorship Collaborators as Business Elites

\section{List of Tables}

A.1 Board members with high-positions during the dictatorship $\ldots \ldots \ldots$ ii

A.2 Robustness of working in a board results $\ldots \ldots \ldots \ldots$ iii

A.3 Robustness of working in a high-position results . . . . . . . iv

A.4 Robustness of board compensation results $\ldots \ldots \ldots \ldots \ldots \ldots$ v

A.5 Robustness of results to collapse years into political periods . . . . . . . vi 
Table A.1: Board members with high-positions during the dictatorship

\begin{tabular}{|c|c|c|c|c|}
\hline & \multicolumn{4}{|c|}{ Works in board } \\
\hline & \multicolumn{2}{|c|}{ Indicator } & \multicolumn{2}{|c|}{ Number of boards } \\
\hline & (1) & (2) & (3) & (4) \\
\hline Collaborator $\times$ Democracy & $\begin{array}{c}-0.203^{* * *} \\
(0.077)\end{array}$ & & $\begin{array}{c}-0.321^{* * *} \\
(0.108)\end{array}$ & \\
\hline$\times$ Transition & $\begin{array}{c}-0.165^{* *} \\
(0.082)\end{array}$ & & $\begin{array}{l}-0.149 \\
(0.114)\end{array}$ & \\
\hline Military $\times$ Democracy & & $\begin{array}{c}-0.423^{* * *} \\
(0.091)\end{array}$ & & $\begin{array}{c}-0.558^{* * *} \\
(0.194)\end{array}$ \\
\hline$\times$ Transition & & $\begin{array}{l}-0.280^{*} \\
(0.153)\end{array}$ & & $\begin{array}{l}-0.353 \\
(0.238)\end{array}$ \\
\hline Civilian $\times$ Democracy & & $\begin{array}{l}-0.146^{*} \\
(0.082)\end{array}$ & & $\begin{array}{l}-0.226^{*} \\
(0.117)\end{array}$ \\
\hline$\times$ Transition & & $\begin{array}{l}-0.135 \\
(0.083)\end{array}$ & & $\begin{array}{l}-0.068 \\
(0.121)\end{array}$ \\
\hline Board members & 208 & 208 & 208 & 208 \\
\hline Observations & 2,421 & 2,421 & 1,872 & 1,872 \\
\hline R-squared & 0.611 & 0.612 & 0.811 & 0.811 \\
\hline Fixed effects & $\mathrm{x}$ & $\mathrm{x}$ & $\mathrm{x}$ & $x$ \\
\hline
\end{tabular}

Notes: These regressions use a restricted sample of individuals working in high-positions during the dictatorship period. Fixed effects for each individual and year in the data. Robust standard errors are doubly clustered by board members and firms. Significance level: *** $p<0.01,{ }^{* *} p<0.05,{ }^{*} p<0.1$. See paper for details. 
Table A.2: Robustness of working in a board results

Dependent variable is an indicator for individuals working in a board (any position)

\begin{tabular}{|c|c|c|c|c|c|c|c|c|}
\hline \multirow{3}{*}{$\begin{array}{l}\text { Characteristic } \\
\text { interacted with } \\
\text { period indicators: }\end{array}$} & \multicolumn{4}{|c|}{ Firm characteristics } & \multicolumn{4}{|c|}{ Board member characteristics } \\
\hline & \multicolumn{2}{|c|}{$\begin{array}{l}\text { Indicator for } \\
\text { firms privatized } \\
\text { by the regime }\end{array}$} & \multicolumn{2}{|c|}{$\begin{array}{l}\text { Number of } \\
\text { board members } \\
\text { in firm }\end{array}$} & \multicolumn{2}{|c|}{$\begin{array}{c}\text { Age of } \\
\text { board member }\end{array}$} & \multicolumn{2}{|c|}{$\begin{array}{l}\text { Indicator for } \\
\text { university degree } \\
\text { of board member }\end{array}$} \\
\hline & (1) & $(2)$ & (3) & (4) & (5) & (6) & (7) & $(8)$ \\
\hline Collaborator $\times$ Democracy & $\begin{array}{l}-0.091^{* *} \\
(0.043)\end{array}$ & & $\begin{array}{c}-0.105^{* *} \\
(0.044)\end{array}$ & & $\begin{array}{c}-0.110^{* *} \\
(0.045)\end{array}$ & & $\begin{array}{c}-0.128^{* *} \\
(0.052)\end{array}$ & \\
\hline$\times$ Transition & $\begin{array}{l}-0.035 \\
(0.047)\end{array}$ & & $\begin{array}{l}-0.049 \\
(0.050)\end{array}$ & & $\begin{array}{l}-0.053 \\
(0.050)\end{array}$ & & $\begin{array}{l}-0.049 \\
(0.062)\end{array}$ & \\
\hline Military $\times$ Democracy & & $\begin{array}{c}-0.211^{* * *} \\
(0.072)\end{array}$ & & $\begin{array}{c}-0.246^{* * *} \\
(0.077)\end{array}$ & & $\begin{array}{c}-0.255^{* * *} \\
(0.077)\end{array}$ & & $\begin{array}{c}-0.295^{* * *} \\
(0.084)\end{array}$ \\
\hline$\times$ Transition & & $\begin{array}{l}-0.123^{*} \\
(0.066)\end{array}$ & & $\begin{array}{l}-0.158^{* *} \\
(0.072)\end{array}$ & & $\begin{array}{l}-0.166^{* *} \\
(0.073)\end{array}$ & & $\begin{array}{c}-0.198^{* *} \\
(0.094)\end{array}$ \\
\hline Civilian $\times$ Democracy & & $\begin{array}{l}-0.054 \\
(0.046)\end{array}$ & & $\begin{array}{l}-0.061 \\
(0.046)\end{array}$ & & $\begin{array}{l}-0.065 \\
(0.047)\end{array}$ & & $\begin{array}{l}-0.083 \\
(0.055)\end{array}$ \\
\hline$\times$ Transition & & $\begin{array}{l}-0.008 \\
(0.056)\end{array}$ & & $\begin{array}{l}-0.015 \\
(0.058)\end{array}$ & & $\begin{array}{l}-0.018 \\
(0.058)\end{array}$ & & $\begin{array}{l}-0.009 \\
(0.070)\end{array}$ \\
\hline Board members & 1,111 & 1,111 & 1,111 & 1,111 & 1,092 & 1,092 & 531 & 531 \\
\hline Observations & 13,698 & 13,698 & 13,698 & 13,698 & 13,428 & 13,428 & 8,001 & 8,001 \\
\hline R-squared & 0.606 & 0.607 & 0.830 & 0.830 & 0.606 & 0.606 & 0.609 & 0.610 \\
\hline Fixed effects & $\mathrm{x}$ & $\mathrm{x}$ & $\mathrm{x}$ & $\mathrm{x}$ & $\mathrm{x}$ & $\mathrm{x}$ & $\mathrm{x}$ & $\mathrm{x}$ \\
\hline Mean of dependent variable & 0.847 & 0.847 & 0.847 & 0.847 & 0.849 & 0.849 & 0.840 & 0.840 \\
\hline
\end{tabular}

Notes: Fixed effects for each individual and year in the data. Robust standard errors are doubly clustered by board members and firms. Significance level: ${ }^{* *} p<0.01,{ }^{* *} p<0.05,{ }^{*} p<0.1$. See paper for details 
Table A.3: Robustness of working in a high-position results

Dependent variable is an indicator for individuals working in a high-position

\begin{tabular}{|c|c|c|c|c|c|c|c|c|}
\hline \multirow{3}{*}{$\begin{array}{l}\text { Characteristic } \\
\text { interacted with } \\
\text { period indicators: } \\
\text { Collaborator } \times \text { Democracy }\end{array}$} & \multicolumn{4}{|c|}{ Firm characteristics } & \multicolumn{4}{|c|}{ Board member characteristics } \\
\hline & \multicolumn{2}{|c|}{$\begin{array}{l}\text { Indicator for } \\
\text { firms privatized } \\
\text { by the regime }\end{array}$} & \multicolumn{2}{|c|}{$\begin{array}{c}\text { Number of } \\
\text { board members } \\
\text { in firm }\end{array}$} & \multicolumn{2}{|c|}{$\begin{array}{l}\text { Age of } \\
\text { board member }\end{array}$} & \multicolumn{2}{|c|}{$\begin{array}{c}\text { Indicator for } \\
\text { university degree } \\
\text { of board member }\end{array}$} \\
\hline & $\begin{array}{c}(1) \\
-0.133^{* * *} \\
(0.041)\end{array}$ & $(2)$ & $\begin{array}{c}(3) \\
-0.139^{* * *} \\
(0.042)\end{array}$ & (4) & $\begin{array}{c}(5) \\
-0.142^{* * *} \\
(0.041)\end{array}$ & (6) & $\begin{array}{c}(7) \\
-0.143^{* * *} \\
(0.047)\end{array}$ & (8) \\
\hline$\times$ Transition & $\begin{array}{c}-0.089^{* *} \\
(0.037)\end{array}$ & & $\begin{array}{c}-0.094^{* *} \\
(0.038)\end{array}$ & & $\begin{array}{c}-0.097^{* *} \\
(0.037)\end{array}$ & & $\begin{array}{c}-0.099^{* *} \\
(0.042)\end{array}$ & \\
\hline Military $\times$ Democracy & & $\begin{array}{c}-0.168^{* *} \\
(0.076)\end{array}$ & & $\begin{array}{c}-0.179^{* *} \\
(0.076)\end{array}$ & & $\begin{array}{c}-0.180^{* *} \\
(0.074)\end{array}$ & & $\begin{array}{c}-0.234^{* * *} \\
(0.089)\end{array}$ \\
\hline$\times$ Transition & & $\begin{array}{l}-0.104 \\
(0.064)\end{array}$ & & $\begin{array}{l}-0.115^{*} \\
(0.065)\end{array}$ & & $\begin{array}{l}-0.116^{*} \\
(0.064)\end{array}$ & & $\begin{array}{l}-0.140^{*} \\
(0.080)\end{array}$ \\
\hline Civilian $\times$ Democracy & & $\begin{array}{c}-0.123^{* * *} \\
(0.044)\end{array}$ & & $\begin{array}{c}-0.126^{* * *} \\
(0.045)\end{array}$ & & $\begin{array}{c}-0.130^{* * *} \\
(0.044)\end{array}$ & & $\begin{array}{c}-0.118^{* *} \\
(0.049)\end{array}$ \\
\hline$\times$ Transition & & $\begin{array}{c}-0.084^{* *} \\
(0.038)\end{array}$ & & $\begin{array}{c}-0.088^{* *} \\
(0.039)\end{array}$ & & $\begin{array}{c}-0.091^{* *} \\
(0.039)\end{array}$ & & $\begin{array}{c}-0.089^{* *} \\
(0.043)\end{array}$ \\
\hline Board members & 1,111 & 1,111 & 1,111 & 1,111 & 1,092 & 1,092 & 531 & 531 \\
\hline Observations & 13,698 & 13,698 & 13,698 & 13,698 & 13,428 & 13,428 & 8,001 & 8,001 \\
\hline R-squared & 0.734 & 0.734 & 0.763 & 0.763 & 0.732 & 0.732 & 0.737 & 0.737 \\
\hline Fixed effects & $\mathrm{x}$ & $\mathrm{x}$ & $\mathrm{x}$ & $\mathrm{x}$ & $\mathrm{x}$ & $\mathrm{x}$ & $\mathrm{x}$ & $\mathrm{x}$ \\
\hline Mean of dependent variable & 0.142 & 0.142 & 0.142 & 0.142 & 0.140 & 0.140 & 0.157 & 0.157 \\
\hline
\end{tabular}

Notes: Fixed effects for each individual and year in the data. Robust standard errors are doubly clustered by board members and firms. Significance level: ${ }^{* *} p<0.01,{ }^{* *} p<0.05,{ }^{*} p<0.1$. See paper for details. 
Table A.4: Robustness of board compensation results

Dependent variable is the logarithm of board compensation

\begin{tabular}{|c|c|c|c|c|c|c|c|c|}
\hline \multirow{3}{*}{$\begin{array}{l}\text { Characteristic } \\
\text { interacted with } \\
\text { period indicators: }\end{array}$} & \multicolumn{4}{|c|}{ Firm characteristics } & \multicolumn{4}{|c|}{ Board member characteristics } \\
\hline & \multicolumn{2}{|c|}{$\begin{array}{l}\text { Indicator for } \\
\text { firms privatized } \\
\text { by the regime }\end{array}$} & \multicolumn{2}{|c|}{$\begin{array}{l}\text { Number of } \\
\text { board members } \\
\text { in firm }\end{array}$} & \multicolumn{2}{|c|}{$\begin{array}{l}\text { Age of } \\
\text { board member }\end{array}$} & \multicolumn{2}{|c|}{$\begin{array}{c}\text { Indicator for } \\
\text { university degree } \\
\text { of board member }\end{array}$} \\
\hline & (1) & (2) & (3) & (4) & (5) & (6) & (7) & (8) \\
\hline Collaborator $\times$ Democracy & $\begin{array}{l}-0.464 \\
(0.324)\end{array}$ & & $\begin{array}{l}-0.368 \\
(0.352)\end{array}$ & & $\begin{array}{l}-0.403 \\
(0.310)\end{array}$ & & $\begin{array}{l}-0.540^{*} \\
(0.288)\end{array}$ & \\
\hline$\times$ Transition & $\begin{array}{l}0.507^{* *} \\
(0.200)\end{array}$ & & $\begin{array}{c}0.508^{* * *} \\
(0.033)\end{array}$ & & $\begin{array}{c}0.497^{* * *} \\
(0.035)\end{array}$ & & $\begin{array}{l}0.472^{* *} \\
(0.220)\end{array}$ & \\
\hline Military $\times$ Democracy & & $\begin{array}{l}-0.105 \\
(0.264)\end{array}$ & & $\begin{array}{l}-0.353 \\
(0.345)\end{array}$ & & $\begin{array}{l}-0.095 \\
(0.359)\end{array}$ & & $\begin{array}{l}-0.045 \\
(0.306)\end{array}$ \\
\hline$\times$ Transition & & $\begin{array}{l}0.783^{* *} \\
(0.337)\end{array}$ & & $\begin{array}{l}0.787^{* *} \\
(0.338)\end{array}$ & & $\begin{array}{l}0.765^{* *} \\
(0.341)\end{array}$ & & $\begin{array}{l}0.768^{*} \\
(0.386)\end{array}$ \\
\hline Civilian $\times$ Democracy & & $\begin{array}{l}-0.537 \\
(0.347)\end{array}$ & & $\begin{array}{l}-0.414 \\
(0.386)\end{array}$ & & $\begin{array}{l}-0.471 \\
(0.332)\end{array}$ & & $\begin{array}{c}-0.625^{* *} \\
(0.311)\end{array}$ \\
\hline$\times$ Transition & & $\begin{array}{c}0.397 \\
(0.250)\end{array}$ & & $\begin{array}{c}0.397 \\
(0.252)\end{array}$ & & $\begin{array}{c}0.390 \\
(0.252)\end{array}$ & & $\begin{array}{c}0.358 \\
(0.267)\end{array}$ \\
\hline Board member-firm & 430 & 430 & 430 & 430 & 421 & 421 & 325 & 325 \\
\hline Observations & 1,135 & 1,135 & 1,134 & 1,134 & 1,107 & 1,107 & 861 & 861 \\
\hline R-squared & 0.807 & 0.806 & 0.813 & 0.813 & 0.812 & 0.811 & 0.800 & 0.800 \\
\hline Fixed effects & $\mathrm{x}$ & $\mathrm{x}$ & $x$ & $x$ & $\mathrm{x}$ & $\mathrm{x}$ & $\mathrm{x}$ & $\mathrm{x}$ \\
\hline
\end{tabular}

Notes: Fixed effects for each individual and year in the data. Robust standard errors are doubly clustered by board members and firms. Significance level: ${ }^{* *} p<0.01{ }^{* *} p<0.05,^{*} p<0.1$. See paper for details. 
Table A.5: Robustness of results to collapse years into political periods

\begin{tabular}{|c|c|c|c|c|c|c|c|c|}
\hline & \multicolumn{4}{|c|}{ Work in a board } & \multicolumn{4}{|c|}{ Work in a high-position } \\
\hline & \multicolumn{2}{|c|}{ Indicator } & \multicolumn{2}{|c|}{ Number of boards } & \multicolumn{2}{|c|}{ Indicator } & \multicolumn{2}{|c|}{ Number of boards } \\
\hline & (1) & (2) & (3) & (4) & (5) & (6) & $(7)$ & $(8)$ \\
\hline Collaborator $\times$ Democracy & $\begin{array}{c}-0.106^{* *} \\
(0.044)\end{array}$ & & $\begin{array}{c}-0.921^{* * *} \\
(0.306)\end{array}$ & & $\begin{array}{c}-0.138^{* * *} \\
(0.042)\end{array}$ & & $\begin{array}{c}-0.478^{* * *} \\
(0.146)\end{array}$ & \\
\hline$\times$ Transition & $\begin{array}{l}-0.050 \\
(0.050)\end{array}$ & & $\begin{array}{l}-0.341 \\
(0.219)\end{array}$ & & $\begin{array}{l}-0.094^{* *} \\
(0.038)\end{array}$ & & $\begin{array}{c}-0.240^{* *} \\
(0.111)\end{array}$ & \\
\hline Military $\times$ Democracy & & $\begin{array}{c}-0.246^{* * *} \\
(0.077)\end{array}$ & & $\begin{array}{c}-1.409^{* *} \\
(0.555)\end{array}$ & & $\begin{array}{c}-0.179^{* *} \\
(0.076)\end{array}$ & & $\begin{array}{c}-0.711^{* * *} \\
(0.248)\end{array}$ \\
\hline$\times$ Transition & & $\begin{array}{c}-0.158^{* *} \\
(0.073)\end{array}$ & & $\begin{array}{c}-0.698^{* *} \\
(0.339)\end{array}$ & & $\begin{array}{l}-0.115^{*} \\
(0.065)\end{array}$ & & $\begin{array}{l}-0.337^{*} \\
(0.199)\end{array}$ \\
\hline Civilian $\times$ Democracy & & $\begin{array}{l}-0.063 \\
(0.046)\end{array}$ & & $\begin{array}{l}-0.744^{* *} \\
(0.354)\end{array}$ & & $\begin{array}{c}-0.126^{* * *} \\
(0.045)\end{array}$ & & $\begin{array}{c}-0.394^{* *} \\
(0.175)\end{array}$ \\
\hline$\times$ Transition & & $\begin{array}{l}-0.017 \\
(0.058)\end{array}$ & & $\begin{array}{c}-0.212 \\
(0.264)\end{array}$ & & $\begin{array}{c}-0.087^{* *} \\
(0.039)\end{array}$ & & $\begin{array}{c}-0.204 \\
(0.131)\end{array}$ \\
\hline Board members & 1,111 & 1,111 & 1,111 & 1,111 & 1,111 & 1,111 & 1,111 & 1,111 \\
\hline Observations & 4,566 & 4,566 & 3,312 & 3,312 & 4,566 & 4,566 & 3,312 & 3,312 \\
\hline R-squared & 0.697 & 0.698 & 0.767 & 0.767 & 0.824 & 0.824 & 0.867 & 0.867 \\
\hline Fixed effects & $\mathrm{x}$ & $\mathrm{x}$ & $x$ & $\mathrm{x}$ & $\mathrm{x}$ & $\mathrm{x}$ & $\mathrm{x}$ & $\mathrm{x}$ \\
\hline Mean of dependent variable & 0.847 & 0.847 & 2.244 & 2.244 & 0.142 & 0.142 & 0.374 & 0.374 \\
\hline
\end{tabular}

Notes: Fixed effects for each individual and year in the data. Robust standard errors are doubly clustered by board members and firms. Significance level: ${ }^{* * *} p<0.01{ }^{* *} p<0.05,{ }^{*} p<0.1$. 